\title{
ECONOMIC EVALUATION OF RAINBOW TROUT (Oncorhynchus mykiss) FARMING FED WITH DIFFERENT COMPOSITION FEED
}

\author{
Milorad Mirilović1, Vlado Teodorović, Radmila Marković, \\ Aleksandra Aleksić-Agelidis, Branislav Vejnović, \\ Spomenka Đurić, Dragoljub Jovanović \\ University of Belgrade, Faculty of Veterinary Medicine \\ Belgrade, Serbia
}

\section{Abstract}

This paper evaluates the effects of two different feeds on production results and economic performance in the rainbow trout (Oncorhynchus mykiss) farming. The first group (O-1) was fed with a standard complete pelleted feed, and the second group (O-2) was fed with combined feed consisting of $75 \%$ pellets and $25 \%$ of sardines. Better results were obtained with the O-2 group, while the O-1 group achieved results characteristic for local farming conditions and feed quality. Experimental group O-2 had significantly higher $(p<0,01)$ growth rate when compared to group O-1. Considering current feed and final product (fish) prices in the market, better results in terms of cost-effectiveness were obtained $(\mathrm{E}>0,00)$ in $\mathrm{O}-2$ group of trout fed with the combined meal.

Keywords: rainbow trout, feed, growth rate, cost-effectiveness

\footnotetext{
${ }^{1}$ Corresponding author: mija@vet.bg.ac.rs
} 


\title{
UPOREDNA ANALIZA PROIZVODNIH I EKONOMSKIH POKAZATELJA U INTENZIVNOJ PROIZVODNJI KALIFORNIJSKE PASTRMKE (Oncorhynchus mykiss) HRANJENE OBROCIMA RAZLIČITOG SASTAVA
}

\author{
Milorad Mirilović, Vlado Teodorović, Radmila \\ Marković, Aleksandra Aleksić-Agelidis, \\ Branislav Vejnović, Spomenka Đurić, Dragoljub Jovanović \\ Univerzitet u Beogradu, Fakultet veterinarske medicine, Srbija
}

\section{Kratak sadržaj}

U radu je ispitivan uticaj ishrane kalifornijske pastrmke (Oncorhynchus mykiss) sa dva obroka različitog sastava na proizvodno-ekonomske rezultate. Eksperiment je postavljen sa dve grupe kalifornijske pastrmke: O-1 hranjena je standardnom kompletnom peletiranom hranom i O-2 koja je hranjena kombinovanim obrokom. Bolji rezultat je ostvaren kod O-2 grupe, dok je O-1 grupa postigla rezultate karakteristične za kvalitet domaće hrane i uslove držanja u našoj zemlji. Ogledna grupa O-2 imala je signifikantno veći $(p<0,01)$ ukupni prirast u odnosu na $\mathrm{O}-1$. Pri važećim tržišnim cenama hraniva i konzumne ribe kao finalnog proizvoda, bolji ekonomski rezultati $(\mathrm{E}=2,06)$ postignuti su korišćenjem kombinovanog obroka kod O-2 grupe.

Ključne reči: kalifornijska pastrmka, ishrana, prirast, ekonomika.

\section{INTRODUCTION}

Fish production as well as nutrition has developed significantly in recent years (Azis at al., 2011). Good nutrition in animal production systems is essential to economically produce a healthy, high quality product. In fish farming, nutrition is critical because feeding represents almost half of the production costs.

Rainbow trout is one of the most important Salmonide species of major economic interest for commercial culturing worldwide and it is the dominant type of trout farming in the Balkans (Vranić, 2012). The type of feed and the feeding process itself are among the most important factors influencing trout growth, feed utilization and tissue composition in intensive production. Salmonide feed costs constitute more than $40 \%$ of the production cost (Azevedo P.A., 2004). Thus, much work has been done to create the optimal nutritional requirements, feeding process, growth and feed conversion ratios of salmonids 
(Okumus at al., 2002). Much effort has been and is still put into creating feed composition best for developing balanced commercial diets that promote optimal growth and health with minimal production cost.

In order to make production cheaper in intensive farming system, it is necessary to provide cost-effective feed which can satisfy trout biological and nutritional needs. Cost-effective feed is achieved by introducing raw material substitute for more expensive feed (Weatherup R.N., 1997, Kiang, 1999, Sredanović et al., 2002). Due to the importance of increased production in salmonidae intensive farming system, in this study we evaluated the effects of substituting expensive pelleted feed with a cheaper one, and its impact on the economics of rainbow trout production.

\section{MATERIALS AND METHODS}

A 90 day feeding trial was conducted in rainbow trout pond with all necessary facilities for trout culture farming. The pond is located at an altitude over $200 \mathrm{~m}$ and is supplied by quality water from a river source by direct gravity. Rainbow trout (Oncorhynchus mykiss-Walbaum) with the average weight of $90 \mathrm{~g}$ and length of 190-210 $\mathrm{mm}$ was used in the experiment. The fish were divided into two experimental groups, $\mathrm{O}-1$ and $\mathrm{O}-2$, and placed in the separated pools, 1320 trout in each one.

The experimental group O-1 was fed with a standard pelleted mixture, while the experimental group $0-2$ was fed with mixture of $75 \%$ pellets and $25 \%$ sardines. At the beginning of the experiment the length and average weight of the fish were recorded, and at the end of experiment the weight gain, feed intake, feed conversion ratio (FCR), and the economics of production were examined.

According to the feed formulation specification and crude cost, the price of one kilogram feed for each group was calculated. Economic indicators (cost-efficiency, the cost price and the financial results) were calculated at the end of experiment over actual values and costs of production. Retail prices of certain raw materials used for the feed preparation were taken from the last quarter of year 2015, as well as the retail price of fish on the market.

The price of one kilogram of feed (pellets), for O-1 experimental group was 135,00 dinars, while the price of one kilogram of feed for O-2 experimental group was 115,00 dinars ( $750 \mathrm{gr}$ of pellets and $250 \mathrm{gr}$ of sardelas). Retail price for one kilogram of trout was 600,00 dinars.

The calculation of fish farming cost has been evaluated so that the amortization costs, farm staffing cost, indirect costs, costs of starting material and 
other costs (electric energy, water aeration) were fixed for both groups, but only the cost of feed was variable.

The obtained results were analyzed using descriptive statistical values. Descriptive parameters such as arithmetic mean, standard deviation, variation interval, coefficients of variation were used. Statistically significant result between experimental groups was evaluated based on $p$ value.

Statistical analysis of the results was elaborated using software GrapfPad Prism version 5.00 for Windows, GrapfPad Software, San Diego, California USA, www.graphpad.com. The results were summarized in tables and charts.

\section{RESULTS}

The trout weight gain in both groups over 90 days trial are shown in Chart 1 . At the beginning of the experiment the average weight of trout in both groups were comparable, so there was no significant difference ( $p>0.05)$ between them. However, throughout the experiment a difference in the average trout weight occurred and by the end of the experiment the more weight was obtained in 0 -2 group $(\overline{\mathbf{X}}=156,78 \pm 23,31)$. The average weight of trout in O-1 group was $(\overline{\mathbf{X}}=134,68 \pm 19,80)$.

The difference of the average weight of trout in the 0-2 group compared to the average weight in 0-1 group was 22,10 grams and it was statistically significant $(\mathrm{p}<0,01)$ (Table 1$)$.

Table 1. Measure of variation of trout average weight during the experiment (gr)

\begin{tabular}{|l|c|c|c|c|c|c|}
\hline & Average & $\begin{array}{c}\text { Standard } \\
\text { deviation }\end{array}$ & $\begin{array}{c}\text { Standard } \\
\text { errors }\end{array}$ & $\begin{array}{c}\text { Coeffi- } \\
\text { cient of } \\
\text { variation }\end{array}$ & Min & Max \\
\hline Day 1 \\
\hline O-1 & 88,87 & 8,36 & 0,59 & 9,41 & 75,97 & 102,57 \\
\hline O-2 & 88,98 & 8,05 & 0,65 & 10,28 & 75,97 & 102,57 \\
\hline O-1 & $134,68^{\text {a }}$ & 19,80 & 1,40 & 14,70 & 96,82 & 192,43 \\
\hline O-2 & $156,78^{\text {a }}$ & 23,31 & 1,65 & 14,87 & 102,57 & 213,20 \\
\hline
\end{tabular}

the same letters a show signifficant difference $(p<0,01)$ 


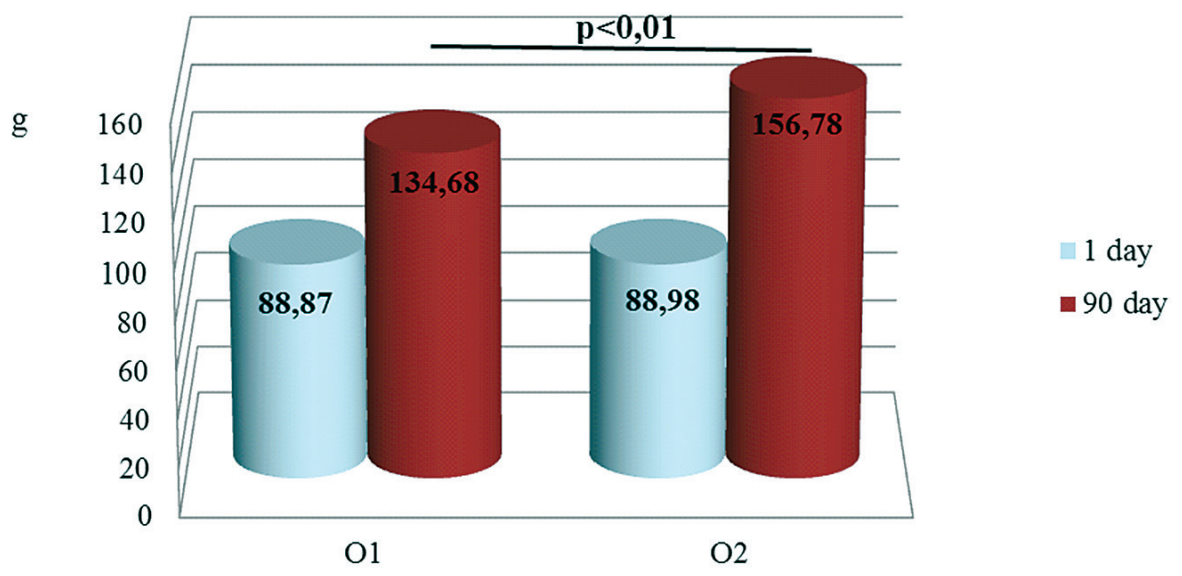

Chart 1. The average trout weight gain during the experiment

Changes in the total and daily weight gain and feed intake of trout in both groups is shown in Table 2 . The better growth was achieved by trout in $0-2$ group, with total weight gain of $67,80 \mathrm{~g}$ or $0,75 \mathrm{~g}$ per day, which is signifficante higher growth than the $\mathrm{O}-1$ group trout $(\mathrm{p}<0,05)$.

Table 2. Total and daily change in weight gain and feed intake

\begin{tabular}{|c|c|c|}
\hline \multirow{2}{*}{} & \multicolumn{2}{|c|}{ Group } \\
\cline { 2 - 3 } O-1 & O-2 \\
\hline \multicolumn{2}{|c|}{ Weight gain from 0 to 90 day, grams } \\
\hline - Total & $45,81^{\mathrm{a}}$ & $67,80^{\mathrm{a}}$ \\
\hline - Daily & 0,51 & 0,75 \\
\hline Feed konsumption from 0 to 90 day, grams \\
\hline - Total & 87,89 & 78,38 \\
\hline - Daily & 0,98 & 0,86 \\
\hline \multicolumn{3}{|c|}{ FCR } \\
\hline - Total & 1,92 & 1,16 \\
\hline
\end{tabular}

the same letters a show signifficant difference $(p<0,05)$

FCR-Feed conversion ratio 


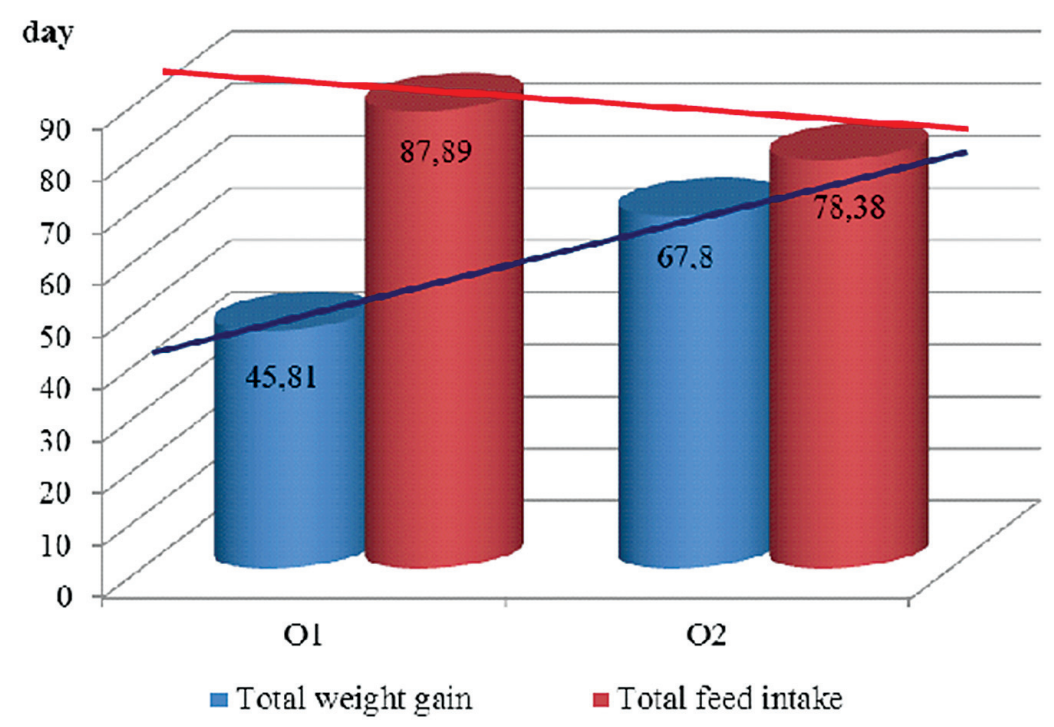

Chart 2. Total weight gain and total feed intake ratio

At the end of the experiment the total and daily feed intake of trout in $0-2$ group was 78.38 and $0.86 \mathrm{~g}$ respectively. The less satisfying results regarding total weight gain were obtained in the $\mathrm{O}-1$ group, where the total and daily feed intake was $87,89 \mathrm{~g}$ and $0,98 \mathrm{~g}$ respectively. The better feed conversion ratio was achieved in the $0-1$ group $(1,16)$.

Feed costs were calculated as the result of price and quantity of feed used (O-1 group 13.349,00 dinars.; O-2 group 10.394,00 dinars). Production value was calculated as the result of the gained fish weight (O-1 group 106.667,00 dinars, O-2 group 124.170,00 dinars) and retail fish price per kilogram (600,00 $\mathrm{din} / \mathrm{kg}$ ). The financial result is the difference between production value and production costs, and cost-effectiveness is a ratio between the value and cost.

Table 3. Financial data generated by groups

\begin{tabular}{|c|c|c|}
\hline Results & $\mathbf{O}-\mathbf{1}$ & $\mathbf{O}-\mathbf{2}$ \\
\hline Total cost & 63.349 & 60.394 \\
\hline Production value & 106.667 & 124.170 \\
\hline Financial result & +43.318 & +63.776 \\
\hline Cost price kg & 356,33 & 291,83 \\
\hline Cost-effectiveness ratio & 1,68 & 2,06 \\
\hline
\end{tabular}




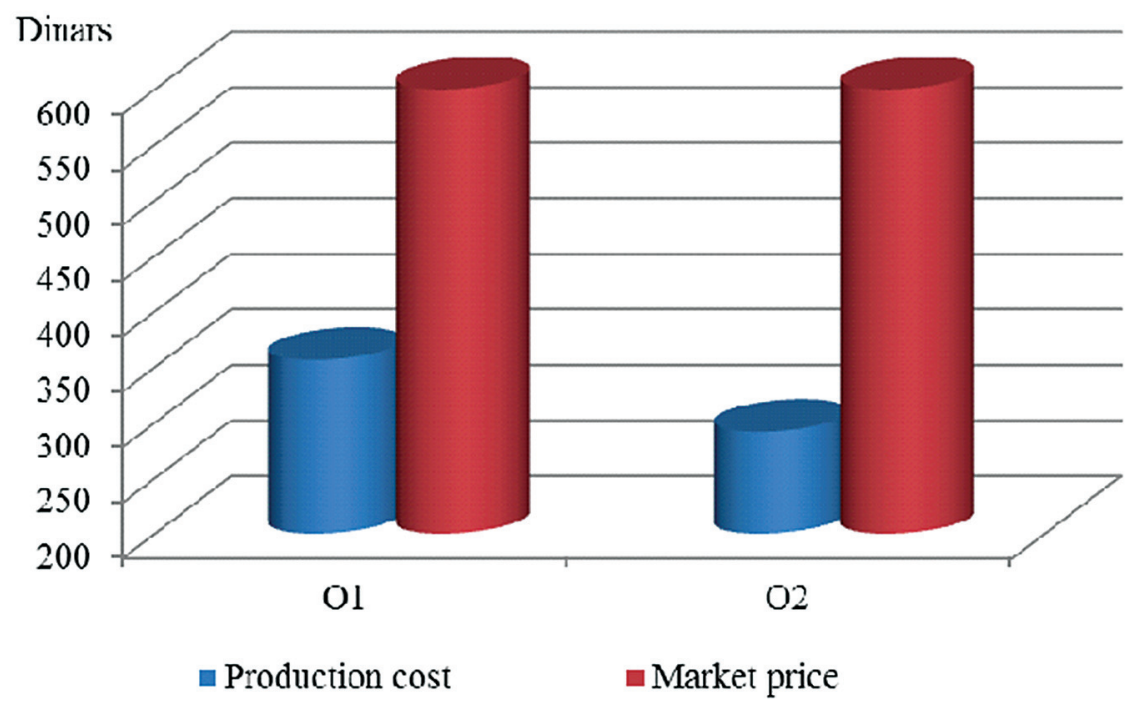

Chart 3 Production cost and market price ratio per kg

Production value in O-2 group is $16,41 \%$ higher from the production value in O-1 group. Financial result in both group was positive. The kilogram of fresh trout in O-2 group had lower cost price when compared to O-1 (291,83,00 dinars). Cost-effectiveness ratio was better in O-2 group $(2,06)$, while in $\mathrm{O}-1$ group was 1,68 .

\section{DISCUSSION}

Optimal feeding is considered as one of the most important factors in intensive farming systems, whereby fish growth is entirely dependent upon the external provision of a nutritionally complete high quality diet (Tacon and al., 1997).

Common problem facing fish farm operation is the need to obtain a balance between rapid fish growth and optimal use of the supplied feed (Gokcek et al., 2008). Since the feed cost accounts approximately for $40-60 \%$ of the operating costs in intensive farming systems (Agung, 2004), the economic viability of the farming operation depends on the feed composition, its nutritional value as well as price of raw materials used in the feed preparation. Although biological needs of fish in terms of protein, energy, vitamin and mineral composition of meals are established, researchers are changing the composition of meals, depending on the types of nutrients available, their costs, production 
process, and the physical characteristics of the pellets used in order to get the best and economical final production results (Alanara, 1992; Tacon, 1993; De Silva et al. 1995).

The goal of this study was to determine the effects obtained by using two different type of feed in rainbow trout (Oncorhynchus mykiss) farming. The production cost were analyzed, and the results of experimental groups have been compared. Food for the experimental group O-1 consisted of trout pellet mixture with standard raw material composition that provided all the essential nutrients as recommended for this trout category (NRC, 1993). Feed for the 0-2 group had a wider ratio of proteins both of animal and plant origin and a lower amount of energy. Based on the trout weight at the beginning and at the end of the experiment, the total and daily weight gain in both groups were calculated.

The achieved results showed that there were significant differences between the $0-2$ group and the $\mathrm{O}-1$ group $(\mathrm{p}<0.05)$. Results of average daily weight gain of trout in other studies ranged from 0,7 to 1, $2 \mathrm{~g}$ (Kulišić and al., 1987; Mijailović et al., 1990; Apostolski et al., 1983; Dalbelo, 1986). However, daily weight gain in our experiment with combined meal was $0,75 \mathrm{~g}$, and according to Kulišić et al. (1986) daily weight gain was 0,66 g, while Mijailović et al. (1990) examining the impact of the combined meal (pellet $+/$ - fish guts) on the performance achieved higher daily weight gain ( $2,14 \mathrm{~g})$ compared to our results.

Feed conversion ratio is one of the best indicators of production effectiveness as well as the feed quality influence on the achieved weight gain. Feed conversion ratio in O-1 group was 1,92 and in O-2 was 1,16. According to the results of Kulišić et al. (1986) who examined the effect of combined meal (pellet + worms), the feeding coefficient of 1,31 was achieved, which is slightly lower than the result obtained in our experiment where meal based on pellets + sardines $(1,16)$ was used. Steffens (1994) research showed that poultry byproduct feed is suitable as a partial or complete replacement, but that complete substitution of feed by poultry by-product and feather meal resulted in reduced weight gain and feed utilization. Fish fed diets with $27 \%$ combined poultry by-product and feather meal without amino acid supplementation had feed conversion ratio of 1,15 .

Considering obtained results it can be concluded that trout feeding with combined meal (pellet + sardines) has nutritional and biological justification. The feeding coefficient in the O-1 group fed with a standard pelleted food was similar to the results obtained by Apostolski et al. (1983) of 1,88 to 2,03, while Mijailovic et al. (1990) reported a conversion coefficient of 2,21, and Dalbelo (1986) of 2,10 to 2,24 . 
Obtained results point that the use of fresh animal feed (O-2) compared to the palette feed (O-1) lowers the cost of feeding. The obtained financial indicators showed that feeding mechanism of group O-2 gives better results in terms of trout growth. This fact points that usage of fresh animal feeding, especially in combination with dry industrial pallets has biological, nutritional and economical justification.

\section{CONCLUSION}

Based on the obtained results the following was concluded:

1. At the and of the experiment the average trout weight in group $\mathrm{O}-2$ $(156,78 \pm 23,31)$ was significantlly higher $(\mathrm{p}<0,01)$ then the average trout weight in group O-1(134,68 19,80$)$.

2. The average weight gain of traout in group O-2 was statistically significant $(p<0,05)$ when compared to the average weight gain in group $\mathrm{O}-1$.

3. The cost-efficiency of production of trout in group O-2 was 2,06 while the ratio in group $\mathrm{O}-1$ was 1,68 .

\section{AKNOWLEDGMETS}

This work is part of research work under the project No. TR 31011 funded by the Ministry of Education, Science and Technological Development of the Republic of Serbia.

\section{LITERATURE}

1. Agung S., Comparism of Lupin meal based diets cost efficiency for juvenile Penaeus monodon tested under pond conditions, Journal of coastal development, 8, 47-51, 2004

2. Alanara A., The effect of time-restricted demand feeding on feeding activity, growth and feed conversion in rainbow trout (Oncorhynchus mykis) in net-pens, Aquaculture, 108, 357-368, 1992

3. Apostolski K, Stevanovski V, Pešav I, Uticaj ishrane na prirast, zdravstveno stanje i kvalitet mesa kod pastrva, Ribarstvo Jugoslavije, 38 (1), 1-5, 1983

4. Azavedo P.A., Leeson S., Cho C.y., Bureau D.P., Growth and feed utlisation of the large size rainbow trout (Oncorhynchus mykiss) and Atlantic salmon (Salmo salar) reared in fresh water: diet and species effects, and responses over time, Aquaculture nutrition, 10, 401-411, 2004

5. Azis A., Khan F., Rab A., Ramzan M., Development of least-cost fish feed 
for rainbow trout form indigenous ingredients at Juglote,Gilgit, Pakistan, Punjab University journal zoology, 26, 53-58, 2011

6. Dalbelo M., Kvalitet peletirane hrane u ishrani konzumne pastrve, Ribarstvo Jugoslavije, 41 (4-5), 84-85, 1986

7. De Silva SS., Anderson T.A., Fish Nutrition in Aquaculture, Caphman \& Hall, London, 1995

8. Gokcek CK, Mazlum Y, Akyurt I., Effects of feeding frequency on the growth and survival of Himri barbell and Barbus luteus fry under laboratory conditions, Pak. J. Nutr., 7, 66-69, 2008

9. Kiang JK., The principles of extruding fishfeed, Animal Feed Science and Technology, 3, 6, 48-49, 1999

10. Kulišić B., Pavlagić Z., Fijan N., Korišćenje otpada u pastrvskoj proizvodnji-pokušaj pripremanja silaže umjetnom probavom lešina, Ribarstvo Jugoslavije, 41, 4-5, 77-78, 1986

11. Kulišić B., Pavlagić Z., Ocjena rezultata prehrane pastrva različitim hranama, Ribarstvo Jugoslavije, 42, 2-3, 36-39, 1987

12. Mijailović M., Rajić I., Modrić P., Nicević V., Petrović S., Mogućnost i opravdanost upotrebe klaničnih i ribljih konfiskata u proizvodnji sveže peletirane hrane za pastrmku, Ribarstvo Jugoslavije, 45, 5, 118-119, 1990

13. National Research Concil, Nutrient Requirements of fish, National Academy of Sciences, Washington, D.C. 1993

14. Okumuus I., Mazlum M., Evaluation of Commercial Trout Feeds: Feed Consumption, Growth, Feed Conversion, Carcass Composition and Bioeconomic Analysis, Turkish Journal of Fisheries and Aquatic Sciences, 2, 101-107, 2002

15. Sredanović S., Đuragić O., Lević J., Nove tehnologije dodavanja tečnosti u hranu za životinje, PTEP, 6, 1-2, 34-38, 2002

16. Steffens W., Replacing fish meal with poultry by-product meal in diets for rainbow trout, Oncorhynchus mykiss, Aquaculture 124, 27-34, 1994

17. Tacon AGJ., Aquacilture nutrition and feeding in developing countries. A practical approach to research and development, IV ${ }^{\text {th }}$ International Symposium on Fish, Les Colloques No. 61, INRA, Paris, 731-741, 1993

18. Tacon AGJ., De Silva S.S., Feed preparation and feed management strategies within semi-intensive fish farming systems in the tropics, Aquaculture 15, 379-404, 1997

19. Vranić D., Uticaj ishrane na kvalitet mesa kalifornijske pastrmke (Oncorhynchus mykiss), Doktorska disertacija, Univerzitet u Beogradu, Fakultet veterinarske medicine, Beograd, 2012 
20. Weatherup R.N., McCracken K.J., Foy R., Rice D., McKendry J., Mairs R.J., Hoey R., The effects of dietary fat content on performance and body composition of farmed rainbow trout (Oncorhynchus mykiss), Aquaculture, $151,1-4,173-184,1997$

Primljeno: 28.11.2015.

Odobreno: 15.01.2016. 